activity, structure and organisation of the cell and its sub-units, including work on viruses. Technical or theoretical papers aiming at the further development of methods in the field of experimental cytology will also be included. Papers may be submitted in English, French or German. It is being edited by Prof. Törbjorn Caspersson, Stockholm; Dr. Honor Fell, Cambridge, England ; Prof. John Runnström, Stockholm; Dr. Francis O. Schmitt, Cambridge, Massachusetts ; Dr. Paul Weiss, Chicago, Illinois ; Dr. Ralph W. C. Wyckoff, Bethesda, Maryland. Prof. J. F. Danielli, London, will act as editor of communications from the Society for Cell Biology. Authors residing in the Americas should send their papers to the American editors; those residing in the British Isles should communicate with Dr. Honor Fell, Strangeways Laboratory, Cambridge; papers originating in other countries should be forwarded to the Scandinavian editors. One volume, consisting of four issues, will be published annually, by the Academic Press, Inc., New York.

\section{Latin American Scléntific Institutions and Workers}

THE Latin American Conference of Scientific Experts, held in Montevideo during September 1948, recommended to Unesco the importance of publishing a classified list of Latin American scientific institutions and men of science. The Lotin American Unesco Field Science Co-operation Office established in Montevideo is making an inquiry for this purpose; at present this inquiry is almost complete for Colombia, Ecuador and Uruguay, while it is at an advanced stage for the Argentine, Brazil, Chile, Bolivia, Peru, Cuba, Mexico, Paraguay, Puerto Rico, San Domingo, Venezuela and Honduras. The aim of this inquiry is to collect data on scientific workers, institutions and societies (addresses, activities, publications, special items, etc.) in order to have a complete set of biographical and technical information to publish later on. All Latin American scientific workers and organisations are invited to send any possible information on their activities to Centro de Cooperación Científica para América Latina de la Unesco, Agraciada 1875, Montevideo.

\section{Cambridge Sciéntists' Anti-War Group}

A CAMBridge Scientists' Anti-War Group has been re-formed; the officers are: Dr. W. A. Wooster (chairman), Mr. P. A. Jewell (secretary), Dr. S. F. Boys (treasurer), and all inquiries should be addressed to 330 Cherry Hinton Road, Cambridge. It is proposed to study and report on questions of international co-operation in science, on factors determining the attitude of the public to war, on the causes of the failure of previous peace treaties and disarmament proposals, on the biological aspects of atomic warfare and bacteriological warfare, and to present alternative contributions which science could make to human welfare if not deflected into war preparations.

\section{Exhibitiop'Overseas Research Scholarships for 1949}

THE Royal Commission for the Exhibition of 1851 announces the award of overseas science research scholarships for 1949 to the following for research work to be carried out at the universities stated. J.R. Allen (Queen's University, Kingston, Ontario), physics at Bristol; G. E. Lee-Whiting (University of Toronto), physics at Bristol, Cambridge or Man- chester ; D. E. Caro (University of Melbourne), physics at Birmingham or Cambridge ; R. L. Martin (University of Melbourne), chemical physics at Cambridge; R. Gradwell (University of Queensland), geology at the Imperial College of Science and Technology, London; L. C. Vining (University of New Zealand), organic chemistry at Cambridge; A. Klug (University of Cape Town), physics at Birmingham, Bristol or Cambridge; K. G. Ramanathan (Indian Institute of Science, Bangalore), physics at Cambridge; M. T. Chaudhary (University of the Punjab), organic chemistry at London; J. E. J. Gowan (National University of Ireland), organic chemistry at University College, London. The scholarships are of the value of $£ 350-400$ a year and are ordinarily tenable for two years.

\section{Institution of Electrical Engineers: Premium Awards}

THE Instiftation of Electrical Engineers has made the following awards of premiums for papers read or accepted for publication during the session 1948-49. Kelvin Premium: C. W. Earp and R. M. Godfrey. John Hopkinson Premium: G. F. Shotter. NonSection Premiums: A. Hamilton and Dr. R. W. Sillars (Llewellyn B. Atkinson Premium); Dr. J. H. Walker (extra premium). Measurements Section Premiums : Prof. F. C. Williams and T. Kilburn (Silvanus Thompson Premium); G. T. Winch (Mather Premium); H. M. Gale and P. D. Atkinson (extra premium). Radio Section Premiums: G. Millington (Duddell Premium); Dr. G. F. Gainsborough (Ambrose Fleming Premium); and extra premiums to H. de B. Knight; Dr. W. A. Wooster, Dr. Nora Wooster, J. L. Rycroft and L. A. Thomas; Dr. D. G. Tucker ; Dr. B. G. Pressey ; Dr. H. G. Hopkins and F. Horner; C. F. Floyd and R. L. Corke; C. F. Booth and J. P. Johns ; H. T. Mitchell and T. Kilvington; F. E. Williams. Supply Section Premiums: H. M. Lacey (Sebastian de Ferranti Premium); H. Headland (John Snell Premium); C. H. Flurscheim and E. L. L'Estrange (extra premium). Utilization Section Premiums : B. Adkins and W. J. Gibbs (Crompton Premium); T. P. Wakeford (Swan Premium). Fahie Premium: W. H. Grinsted. Paris Exhibition (1881) Premium: H. W. Grimmitt. Webber Premium: C. Crampton, W. Struszynski, S. de Walden and P. G. Redgment. Overseas Premium: Dr. H. D. Einhorn and J. D. Sauermann.

\section{Announcements}

THe Managers of the Royal Institution have awarded the Actonian Prize for 1949 of one hundred guineas to Sir Alexander Fleming, for his paper publishod in 1945 entitled "Penicillin-Its Discovery, Development and Uses in the Field of Medicine and Surgery". The Prize has been awarded every seventh year since 1838 under a trust established in that year by the late Mrs. Hannah Acton.

Centennial symposia on "The Mineral Nutrition of Plants" ane "Plant Growth Substances" are being arranged by the University of Wisconsin and will be held at the Memorial Union Theatre during September 1-3 and 5-7, respectively. In addition to-the formal papers, there will be separate sessions for informal discussions. Further information may be obtained from Mr. R. P. Lee, Division of Residence Halls, Slichter Hall, University of Wisconsin, Madison 6, Wisconsin. 